\title{
Simultaneous Determination Of Stock Price Synchronicity And Dividend Payout Ratios: Evidence From The MENA Region
}

Omar Farooq, ADA University, Azerbaijan

Mona A. ElBannan, German University in Cairo, Egypt

\begin{abstract}
This paper examines the determinants of cross-sectional differences in stock price synchronicity and dividend payout ratio in the MENA region during the period between 2003 and 2013. These variables are related not only directly, but also indirectly, through their relationship with information environment of firms. To distinguish these effects, we examine the determinants of both variables within a system of equations. Our results indicate that both of these variables affect each other negatively. We argue that higher information asymmetries associated with firms exhibiting high synchronicity leads to lower payout ratios, while lower information asymmetries that accompany firms paying high dividends lead to lower synchronicity.
\end{abstract}

Keywords: Stock Price Synchronicity; Dividend Policy; Information Environment; Corporate Governance; Emerging Markets

\section{INTRODUCTION}

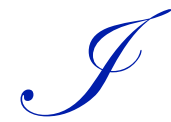

$\mathrm{n}$ this paper, we investigate the determinants of stock price synchronicity and dividend policies within a simultaneous empirical framework. Our analysis builds on prior research on each of these variables and aims to document dependence between these variables. Prior literature documents that both of these variables are the function of information environment associated with firms (Farooq and Ahmed, 2014; Kang and Kim, 2013; Morck et al., 2000; La Porta et al., 2000). Given that the information environment affects both of these variables simultaneously, it can be argued that both of these variables are simultaneously determined. Therefore, it is preferable to study the relationship between these two variables in a common framework. By doing so, we add on to the literature on determinants of dividend policy and stock price synchronicity. To the best of our knowledge, this is the first attempt to relate dividend policy and stock price synchronicity in a simultaneous framework.

This paper argues that stock price synchronicity and dividend policies are determined by the extent of information asymmetries associated with firms. For instance, prior literature documents that information environment of firms is the main determinant of stock price synchronicity (Morck et al., 2000; Jin and Myers, 2006). Farooq and Ahmed (2014), for instance, document higher synchronicity for firms with better governance mechanisms in emerging markets. They show that various proxies for governance environment of a firm (analyst following, operational complexity, and ownership structure) are significant determinants of stock price synchronicity. In another related study, Chan and Hameed (2006) associate analyst following - proxy for information environment of a firm - with high stock price synchronicity. Dasgupta et al. (2010) also come to the same conclusion and argue that positive impact of governance environment on stock price synchronicity is driven by the fact that investors are better able to predict future firm-specific events for firms with better governance environment. Given that stock prices respond only to unanticipated events, accurate forecasts increase the likelihood that prevailing stock prices have already factored in the occurrence of future events. Therefore, when events actually happen, prices do not react significantly to such news, thereby resulting in lower firm-specific variation in stock prices. 
Just as the way information environment affects synchronicity, it also exerts significant influence on the dividend policies adopted by firms. Li and Zhao (2008), for example, find that the extent of agency problems - analyst earnings forecast errors and the dispersion in their forecasts - negatively affect dividends. They document that firms with higher agency problems are less likely to pay, initiate, or increase dividends. They also show that such firms pay small dividends whenever they have to pay relative to firms with lower agency problems. In another related study, La Porta et al. (2000) show that firms in the common law countries have higher dividend payout ratios than firms in the civil law countries. They argue that high payout ratios in the common law countries are due to better information environment prevailing in these countries. ${ }^{1}$ Better information environment constrains insiders from expropriating corporate resources by making expropriation technology expensive. This strand of literature argues that when insider cannot expropriate, they tend to share corporate profit with shareholders. Therefore, there exist a positive relationship between information environment and dividend payouts.

Given that the information environment affects synchronicity and dividend policy simultaneously, this paper hypothesizes that firms with high payout ratios should have low synchronicity and firms with high synchronicity should have low payout ratios. Our hypothesis takes its motivation from the above literature that argues that: (1) High payout ratios are associated with better information environment and better information environment should lead to low synchronicity, and (2) High synchronicity is associated with poor information environment and poor information environment should lead to low payout ratios. Consistent with our hypothesis, this paper shows that synchronicity and payout ratios affect each other negatively in the MENA region during the period between 2003 and 2013.

The remainder of the paper is structured as follows: Section 2 summarizes the data and Section 3 presents the methodology. Section 4 documents our results. The paper ends with Section 5 where we present conclusions.

\section{DATA}

This paper documents the relationship between stock price synchronicity and dividend policy under the assumption that they are simultaneously determined. For the purpose of this paper, we use the data from the MENA region (Egypt, Jordan, Morocco, Qatar, Saudi Arabia, Tunisia, and United Arab Emirates) covering eleven year period between 2003 and 2013. All variables are measured in dollars. We will, briefly, discuss the data in the following sub-sections.

\subsection{Stock Price Synchronicity}

We measure stock price synchronicity $(\mathrm{SYNCH})$ by the coefficient of determination $\left(\mathrm{R}^{2}\right)$ obtained from the estimation of following regression with returns of stock ' $i$ ' during week ' $t$ ' $\left(\mathrm{R}_{\mathrm{i}, \mathrm{t}}\right)$ as a dependent variable and returns of the corresponding market index ' $\mathrm{m}$ ' for the same week $\left(\mathrm{R}_{\mathrm{m}, \mathrm{t}}\right)$ as an independent variable. As is the convention in prior literature, we estimate Equation (1) only for those firms for which we have at least 40 weekly observations of returns in a given year (Farooq and Ahmed, 2014; Xing and Anderson, 2011). The date required to estimate Equation (1) is obtained from the Datastream.

$$
\mathrm{R}_{\mathrm{i}, \mathrm{t}}=\alpha+\beta\left(\mathrm{R}_{\mathrm{m}, \mathrm{t}}\right)+\varepsilon_{\mathrm{i}, \mathrm{t}}
$$
analysis.

Given the bounded nature of $\mathrm{R}^{2}$, we transform it as follows to get a variable that can be used in our

$$
\mathrm{SYNCH}=\log \frac{\mathrm{R}^{2}}{1 \quad \mathrm{R}^{2}}
$$

\footnotetext{
${ }^{1}$ The common law countries are characterized by strong investor protection and superior information environment, while the civil law countries are characterized by weak investor protection and inferior information environment.
}

Copyright by author(s); $\underline{\text { CC-BY }}$ 
Table 1 reports descriptive statistics for stock price synchronicity. Larger values indicate higher synchronicity. Our results show that Egypt has the highest synchronicity. Mean and median values of synchronicity are the highest for Egypt, while they are the lowest for Jordan. On average, our results indicate low level of synchronicity in the MENA region. Low values of synchronicity are in contrast with the arguments of Morck et al. (2000) and Jin and Myers (2006) who suggest high values of synchronicity in opaque environments. Given that firms in the MENA region have inadequate disclosure and governance mechanisms, prior literature would predict high values of synchronicity (Morck et al., 2000; Jin and Myers, 2006). We argue that the main reason behind low values of synchronicity is the under diversification of marginal investors in these markets. Under diversification exposes marginal investors to idiosyncratic risk, thereby allowing them to take into account firm-specific risk while pricing stocks. It will, therefore, reduce the relative amount of market-wide information in stock returns and result in low values of synchronicity.

Table 1. Descriptive statistics for stock price synchronicity

\begin{tabular}{|c|c|c|c|c|}
\hline Countries & Mean & Median & Standard Deviation & No. of Observations \\
\hline Egypt & $-1.8939(0.21)$ & $-1.4931(0.18)$ & $1.7770(0.16)$ & 506 \\
\hline Jordan & $-3.6709(0.08)$ & $-2.9330(0.05)$ & $2.5519(0.10)$ & 150 \\
\hline Morocco & $-2.4860(0.14)$ & $-2.1062(0.10)$ & $1.7028(0.12)$ & 284 \\
\hline Qatar & $-1.9640(0.19)$ & $-1.7076(0.15)$ & $1.6019(0.16)$ & 131 \\
\hline Saudi Arabia & $-3.0695(0.12)$ & $-2.5101(0.07)$ & $2.3846(0.13)$ & 24 \\
\hline Tunisia & $-2.4661(0.16)$ & $-2.1320(0.10)$ & $2.0666(0.14)$ & 28 \\
\hline United Arab Emirates & $-2.5274(0.15)$ & $-2.0348(0.11)$ & $2.2168(0.14)$ & 93 \\
\hline
\end{tabular}

\subsection{Dividend Payout Ratio}

We define dividend policy (PoR) of a firm by dividend payout ratio. Data for dividend payout ratio is obtained from the Worldscope. Descriptive statistics for dividend payout ratio is reported in Table 2. Our results indicate low dividend payout ratios for our sample firms. However, on a relative basis, Jordanian and Tunisian firms have higher dividend payout ratios than their counterpart firms from other countries in the MENA region. We argue that low dividends are driven by weak investor protection in the region. Our argument is consistent with La Porta et al. (2000) and Shleifer and Wolfenzon (2002) who document low payout ratios in countries with weak investor protection mechanisms.

Table 2. Descriptive statistics for dividend payout ratio

\begin{tabular}{l|r|r|r|c}
\hline Countries & Mean & Median & Standard Deviation & No. of Observations \\
\hline Egypt & 8.2523 & 9.1100 & 5.4572 & 506 \\
\hline Jordan & 29.5318 & 0.0000 & 37.2638 & 150 \\
\hline Morocco & 6.7037 & 6.9650 & 3.4052 & 284 \\
\hline Qatar & 11.9222 & 13.4700 & 7.9478 & 131 \\
\hline Saudi Arabia & 12.0626 & 14.3400 & 9.9262 & 24 \\
\hline Tunisia & 31.7728 & 34.8950 & 17.3294 & 28 \\
\hline United Arab Emirates & 8.3412 & 6.5400 & 8.3927 & 93 \\
\hline
\end{tabular}

\subsection{Control Variables}

In order to account for possible effect of firm-specific and country-specific characteristics on stock price synchronicity and dividend payout ratio, we add the following control variables in our analysis.

- SIZE: This paper defines SIZE as the log of market capitalization. Imran et al. (2013) document significant impact of size on dividend payout ratio, while Chan and Hameed (2006) document that size is a significant determinant of stock price synchronicity.

- EPS: We define EPS as earnings per share. Eriostis and Vasiliou (2003) argue that profitable firms are more likely to pay dividends than non-profitable firms, while Dasgupta et al. (2010) document similar impact of profitability on synchronicity. 
- GROWTH: We define GROWTH as growth in total assets. Chen and Dhiensiri (2009) show that high growth firms pay lower dividends, while Farooq and Haleka (2015) document significantly negative relationship between growth and synchronicity.

- MBR: This paper defines MBR as market value to book value ratio. Rahman and Takumi (2012) report negative relationship between market value to book value ratio and dividend payout ratio, while Francis et al. (2012) argue that market value to book value ratio should significantly impact synchronicity.

- PROTECTION: We measure PROTECTION as the extent of investor protection. The data for investor protection is provided by the World Bank. In strong investor protection countries, shareholders can use their power to extract high dividends. Regarding relationship between synchronicity and investor protection, Morck et al. (2000) point towards lower synchronicity in countries with high investor protection.

\section{METHODOLOGY}

A system of equations is the natural technique to address the questions raised by us. Similar estimation techniques have been used in earlier research, such as Jensen et al. (1992) and Aggarwal and Kyaw (2010). Our structural equations take the following form. In the following equations, CDUM is a vector of country dummies, YDUM is a vector of year dummies, and IDUM is a vector of industries dummies. All other variables are as defined above.

$$
\begin{aligned}
& \text { SYNCH }=\alpha+\beta_{1}(\mathrm{POR})+{ }_{\mathrm{i}=1}^{\mathrm{n}} \chi_{\mathrm{i}}(\mathrm{CDUM})+{ }_{\mathrm{i}=1}^{\mathrm{n}} \delta_{\mathrm{i}}(\text { YDUM })+{ }_{\mathrm{i}=1}^{\mathrm{n}} \lambda_{\mathrm{i}}(\text { IDUM })+\varepsilon \\
& \mathrm{PoR}=\alpha+\beta_{1}(\mathrm{SYNCH})+\sum_{\mathrm{i}=1}^{\mathrm{n}} \chi_{\mathrm{i}}(\mathrm{CDUM})+{ }_{\mathrm{i}=1}^{\mathrm{n}} \delta_{\mathrm{i}}(\text { YDUM })+{ }_{\mathrm{i}=1}^{\mathrm{n}} \lambda_{\mathrm{i}}(\text { IDUM })+\varepsilon
\end{aligned}
$$

And

$$
\begin{aligned}
& \text { SYNCH }= \alpha+\beta_{1}(\mathrm{PoR})+\beta_{2}(\mathrm{SIZE})+\beta_{3}(\mathrm{EPS}) \\
&+\beta_{4}(\mathrm{GROWTH})+\beta_{5}(\mathrm{MBR})+\beta_{6}(\text { PROTECTION }) \\
&+{ }_{\mathrm{i}=1}^{\mathrm{n}} \chi_{\mathrm{i}}(\mathrm{CDUM})+{ }_{\mathrm{i}=1}^{\mathrm{n}} \delta_{\mathrm{i}}(\mathrm{YDUM})+{ }_{\mathrm{i}=1}^{\mathrm{n}} \lambda_{\mathrm{i}}(\mathrm{IDUM})+\varepsilon \\
& \mathrm{POR}=\alpha+\beta_{1}(\mathrm{SYNCH})+\beta_{2}(\mathrm{SIZE})+\beta_{3}(\mathrm{EPS}) \\
&+\beta_{4}(\mathrm{GROWTH})+\beta_{5}(\mathrm{MBR})+\beta_{6}(\mathrm{PROTECTION}) \\
&+{ }_{\mathrm{i}=1}^{\mathrm{n}} \chi_{\mathrm{i}}(\mathrm{CDUM})+{ }_{\mathrm{i}=1}^{\mathrm{n}} \delta_{\mathrm{i}}(\mathrm{YDUM})+{ }_{\mathrm{i}=1}^{\mathrm{n}} \lambda_{\mathrm{i}}(\text { IDUM })+\varepsilon
\end{aligned}
$$

We use simultaneous multivariate ordinary least squares to estimate above equations. As a robustness check, the analysis is also conducted in sub-samples of large and small firms. In addition, we also use 2SLS and 3SLS to estimate the above equations.

\section{ANALYSIS AND RESULTS}

\subsection{Relationship between Stock Price Synchronicity and Dividend Payout Ratio}

Table 3 reports results of our analysis by using multivariate ordinary least squares. Our results show that synchronicity and payout ratios affect each other negatively. We report significantly negative coefficients for $\mathrm{SYNCH}$ as well as for PoR for both equations. We argue that as the dividend payout ratios increase, information asymmetries go down, thereby resulting in more informative stock prices. Informative stock prices indicate that firm-specific information constitutes greater proportion of the stock prices. It, therefore, also leads to lower synchronicity (lower coefficient of determination). Similar arguments can be put forwards for the negative impact of synchronicity on dividend payout ratios. We argue that as synchronicity increase, stock prices become less 
informative. It, therefore, provides greater means to insiders to expropriate. As a result, they tend not to share corporate profits with their shareholders, thereby leading to lower payout ratios. An important observation is Table 3 is the low R-squares of the analysis. We argue that the inefficient nature of stock prices in emerging markets, especially the MENA region, makes fundamental information less value relevant than in more developed financial markets.

Table 3. Relationship between stock price synchronicity and dividend payout ratio

\begin{tabular}{|c|c|c|c|c|}
\hline \multirow{2}{*}{ Variables } & \multicolumn{2}{|c|}{ Equation (3) } & \multicolumn{2}{|c|}{ Equation (4) } \\
\hline & SYNCH & PoR & SYNCH & PoR \\
\hline SYNCH & & $-1.1852 * * *$ & & $-1.6599 * * *$ \\
\hline PoR & $-0.0164 * * *$ & & $-0.0193 * * *$ & \\
\hline SIZE & & & $0.3462 * * *$ & 0.2024 \\
\hline EPS & & & $-0.0284 * *$ & $-0.3123 * *$ \\
\hline GROWTH & & & 0.0002 & $0.2780^{* * *}$ \\
\hline MBR & & & -0.0585 & 0.3740 \\
\hline PROTECTION & & & -0.0725 & -0.7543 \\
\hline Fixed Effects & Yes & Yes & Yes & Yes \\
\hline No. of Observations & 1216 & 1216 & 944 & 944 \\
\hline F-Value & 7.20 & 3.14 & 10.04 & 5.58 \\
\hline R-Square & 0.1027 & 0.0475 & 0.1862 & 0.1127 \\
\hline
\end{tabular}

Note: Coefficients with $1 \%$ significance are followed by ***, coefficient with $5 \%$ by **, and coefficients with $10 \%$ by *.

\subsection{Relation between Stock Price Synchronicity and Dividend Payout Ratios in Different Sub-Samples}

As a robustness check, we divide our sample into sub-groups of small and large firms. We re-estimate Equation (4) for both sub-groups. Our results are reported in Table 4. As was reported earlier, we show that synchronicity and payout ratios affect each other negatively in both sub-groups. We report significantly negative coefficients for SYNCH as well as for PoR for both sub-groups.

Table 4. Relationship between stock price synchronicity and dividend payout ratio in different sub-groups

\begin{tabular}{|c|c|c|c|c|}
\hline \multirow{2}{*}{ Variables } & \multicolumn{2}{|c|}{ Small Firms } & \multicolumn{2}{|c|}{ Large Firms } \\
\hline & SYNCH & PoR & SYNCH & PoR \\
\hline SYNCH & & $-1.4229 * * *$ & & $-1.7803 * * *$ \\
\hline PoR & $-0.0152 * * *$ & & $-0.0248 * * *$ & \\
\hline SIZE & $0.5742 * * *$ & -0.2472 & $0.2988 * * *$ & 0.3731 \\
\hline EPS & 0.0155 & $-0.7252^{*}$ & $-0.0395 * * *$ & $-0.2681 * *$ \\
\hline GROWTH & 0.0015 & $0.2929 * * *$ & -0.0057 & $0.2346^{* * *}$ \\
\hline MBR & -0.2132 & 0.5003 & -0.0380 & 0.1849 \\
\hline PROTECTION & 0.1410 & -1.4902 & $-0.2341 *$ & 0.2142 \\
\hline CDUM & Yes & Yes & Yes & Yes \\
\hline YDUM & Yes & Yes & Yes & Yes \\
\hline IDUM & Yes & Yes & Yes & Yes \\
\hline No. of Observations & 396 & 396 & 548 & 548 \\
\hline F-Value & 3.17 & 3.78 & 5.92 & 4.44 \\
\hline R-Square & 0.1444 & 0.1678 & 0.1912 & 0.1505 \\
\hline
\end{tabular}

As a second robustness check, we use alternate estimation procedures - two-stage least square (2SLS) and threestage least square (3SLS) - to test the simultaneous nature of the problem. 2SLS and 3SLS require set of variables that are common to both equations, as well as a set of variables that are specific to a particular equation. The variables that are specific to a particular equation are the instruments that help us to identify the system parameters. The common variables are the ones used in Equation (5). We use the extent of analyst coverage (ANALYST) and intangible asset to total asset ratio (INTANGIBLITY) as variables that effect stock price synchronicity and total debt to total asset ratio (LEVERAGE) and free cash flow per share (FCF) as variables that effect dividend payout ratio. 
The choice of variables is motivated by prior literature that uses these variables as determinant of synchronicity and payout ratios. Our modified equation takes the following form:

$$
\begin{aligned}
\text { SYNCH }= & \alpha+\beta_{1}(\text { POR })+\beta_{2}(\text { SIZE })+\beta_{3}(\text { EPS }) \\
& +\beta_{4}(\text { GROWTH })+\beta_{5}(\text { MBR })+\beta_{6}(\text { PROTECTION }) \\
& +\beta_{7}(\text { ANALYST })+\beta_{8}(\text { INTANGIBILTY }) \\
& +{ }_{\mathrm{i}=1}^{\mathrm{n}} \chi_{\mathrm{i}}(\mathrm{CDUM})+{ }_{\mathrm{i}=1}^{\mathrm{n}} \delta_{\mathrm{i}}(\mathrm{YDUM})+{ }_{\mathrm{i}=1}^{\mathrm{n}} \lambda_{\mathrm{i}}(\text { IDUM })+\varepsilon \\
\text { PoR }= & \alpha+\beta_{1}(\mathrm{SYNCH})+\beta_{2}(\mathrm{SIZE})+\beta_{3}(\mathrm{EPS}) \\
& +\beta_{4}(\text { GROWTH })+\beta_{5}(\mathrm{MBR})+\beta_{6}(\text { PROTECTION }) \\
+ & \beta_{7}(\text { LEVERAGE })+\beta_{8}(\mathrm{FCF}) \\
+ & { }_{\mathrm{i}=1}^{\mathrm{n}} \chi_{\mathrm{i}}(\mathrm{CDUM})+{ }_{\mathrm{i}=1}^{\mathrm{n}} \delta_{\mathrm{i}}(\mathrm{YDUM})+{ }_{\mathrm{i}=1}^{\mathrm{n}} \lambda_{\mathrm{i}}(\text { IDUM })+\varepsilon
\end{aligned}
$$

\begin{tabular}{|c|c|c|c|c|}
\hline \multirow{2}{*}{ Variables } & \multicolumn{2}{|c|}{ 2SLS } & \multicolumn{2}{|c|}{ 3SLS } \\
\hline & SYNCH & PoR & SYNCH & PoR \\
\hline SYNCH & & $-5.3435^{*}$ & & $-5.2890 * *$ \\
\hline PoR & $-0.0550 * *$ & & $-0.0583 * * *$ & \\
\hline SIZE & $0.3136^{* * *}$ & 1.6302 & $0.2941 * * *$ & 1.6066 \\
\hline EPS & $-0.0933 * * *$ & $-0 . .6684 *$ & $-0.0955 * * *$ & $-0.6221 *$ \\
\hline GROWTH & 0.0107 & $0.2060 * * *$ & 0.0114 & $0.2060 * * *$ \\
\hline MBR & -0.0309 & 0.1234 & -0.0241 & 0.0996 \\
\hline PROTECTION & -0.0784 & -0.7517 & -0.0813 & -0.7352 \\
\hline ANALYST & $0.0826^{* *}$ & & $0.0930 * *$ & \\
\hline INTANGIBLE & -1.5127 & & 0.3520 & \\
\hline LEVERAGE & & $0.1640 * * *$ & & $0.1695 * * *$ \\
\hline $\mathrm{FCF}$ & & 0.3248 & & 0.0336 \\
\hline CDUM & Yes & Yes & Yes & Yes \\
\hline YDUM & Yes & Yes & Yes & Yes \\
\hline IDUM & Yes & Yes & Yes & Yes \\
\hline No. of Observations & 828 & 828 & 828 & 828 \\
\hline F-Value & 7.36 & 3.61 & & \\
\hline Chi-Square & & & 182.23 & 87.98 \\
\hline
\end{tabular}

Our results are reported in Table 5. Both estimation procedures confirm our previous findings that synchronicity and payout ratios affect each other negatively. We report significantly negative coefficients for SYNCH as well as for PoR for both estimation procedures.

Table 5. Relationship between stock price synchronicity and dividend payout ratio

\section{CONCLUSION}

This paper uses the data from the MENA region to document the relationship between stock price synchronicity and dividend payout ratio in a simultaneous framework during the period between 2003 and 2013. The simultaneous approach allows for the interdependence of variables, while controlling for effects that other firm characteristics may have on these variables. Our results show that both of these variables - stock price synchronicity and dividend payout ratio - are interdependent and affect each other negatively. We argue that higher information asymmetries associated with firms with high synchronicity have negative impact on payout ratios, while better information environment associated with firms paying high dividends lead to lower synchronicity. 


\section{AUTHOR BIOGRAPHIES}

Omar Farooq is Associate Professor of Finance in ADA University, Azerbaijan. His main area of research is corporate governance in emerging markets.

Mona A. ElBannan is Assistant Professor of Finance in German University in Cairo, Egypt. Her main area of expertise is corporate finance.

\section{REFERENCES}

Aggarwal, R. and Kyaw, N.A., (2010). Capital Structure, Dividend Policy, and Multinationality: Theory Versus Empirical Evidence. International Review of Financial Analysis, 19(2), pp. 140-150.

Chan, K. and Hameed, A., (2006). Stock Return Synchronicity and Analyst Coverage in Emerging Markets. Journal of Financial Economics, 80(1), pp. 115-147.

Chen, J. and Dhiensiri, N., (2009). Determinants of Dividend Policy: The Evidence from New Zealand. International Research Journal of Finance and Economics, 34, pp. 18-28.

Dasgupta, S., Gan, J., and Gao, N. (2010). Transparency, Price Informativeness, and Stock Return Synchronicity: Theory and Evidence. Journal of Financial and Quantitative Analysis, 45(5), pp. 1189-1220.

Eriotis, N. and Vasilou, D., (2003). Dividend Policy: An Empirical Analysis of the Greek Market. International Business and Economics Research Journal, 3(3), pp. 49-57.

Farooq, O. and Ahmed, S., (2014). Stock Price Synchronicity and Corporate Governance Mechanisms: Evidence from an Emerging Market. International Journal of Accounting, Auditing and Performance Evaluation, 10(4), pp. 395-409.

Farooq, O. and Haleka, A., (2015). Stock Price Synchronicity and Firm's Exposure to Financial Crisis: Evidence from Emerging Markets. Working Paper, American University in Cairo, Egypt.

Francis, B., Hasan, I., Song, L., and Yeung, B., (2012). What Determines Bank Stock Price Synchronicity? Global Evidence. Bank of Finland Research Discussion Papers No. 16.

Imran, K., Usman, M., and Nishat, M., (2013). Banks Dividend Policy: Evidence from Pakistan. Economic Modelling, 32, pp. $89-90$.

Jensen, G.R., Solberg, D.P., and Zorn, T.S., (1992). Simultaneous Determination of Insider Ownership, Debt, and Dividend Policies. Journal of Financial and Quantitative Analysis, 27(2), pp.247-263.

Jin, L. and Myers, S., (2006). R ${ }^{2}$ Around the World: New Theory and New Tests. Journal of Financial Economics, 79(2), pp. 257-292.

Kang, S.K. and Kim, H., (2013). R-Squared and Dividend Payout: Evidence from the Korean Market. Emerging Markets Finance and Trade, 49(4), pp. 104-118.

La Porta, R., Lopez-De-Silanes, F., Shleifer, A., and Vishny, R.W., (2000). Agency Problems and Dividend Policies around the World. Journal of Finance, 55(1), pp. 1-33.

Li, K. and Zhao, X., (2008). Asymmetric Information and Dividend Policy. Financial Management, 37(4), pp. 673-694.

Morck, R., Yeung, B. and Yu, W., (2000). The Information Content of Stock Markets: Why do Emerging Markets have Synchronous Stock Price Movements? Journal of Financial Economics, 58(1-2), pp. 215-260.

Rahman, A. and Takumi, H., (2012). Determinants of Dividend Payout Ratio: Evidence from Karachi Stock Exchange (KSE). Journal of Contemporary Issues in Business Research, 1(1), pp.20-27.

Shleifer, A. and Wolfenzon, D., (2002). Investor Protection and Equity Markets. Journal of Financial Economics, 66(1), pp. 3-27.

Xing, X. and Anderson, R., (2011). Stock Price Synchronicity and Public Firm-specific Information. Journal of Financial Markets, 14(2), 259-276. 
NOTES 